Trinity University

Digital Commons @ Trinity

History Faculty Research

History Department

Winter 2020

\title{
John Leamy's Atlantic Worlds: Trade, Religion, and Imperial Transformations in the Spanish Empire and Early Republican Philadelphia
}

Linda K. Salvucci

Trinity University, Isalvucc@trinity.edu

Follow this and additional works at: https://digitalcommons.trinity.edu/hist_faculty

Part of the History Commons

\section{Repository Citation}

Salvucci, L. K. (2020). John Leamy's Atlantic worlds: Trade, religion, and Imperial transformations in the Spanish empire and early Republican Philadelphia. U.S. Catholic Historian, 38(1), 1-24. doi: 10.1353/ cht. 2020.0000

This Article is brought to you for free and open access by the History Department at Digital Commons @ Trinity. It has been accepted for inclusion in History Faculty Research by an authorized administrator of Digital Commons @ Trinity. For more information, please contact jcostanz@trinity.edu. 


\section{PROJECT MUSE}

John Leamy's Atlantic Worlds: Trade, Religion, and Imperial Transformations in the Spanish Empire and Early Republican Philadelphia

Linda K. Salvucci

U.S. Catholic Historian, Volume 38, Number 1, Winter 2020, pp. 1-24 (Article)

Published by The Catholic University of America Press

$\Rightarrow$ For additional information about this article http://muse.jhu,adu/article/748651 


\title{
John Leamy's Atlantic Worlds: Trade, Religion, and Imperial Transformations in the Spanish Empire and Early Republican Philadelphia
}

\author{
Linda K. Salvucci
}

\begin{abstract}
John Leany (1757-1839) accumulated a substantial fortume through trade with the Spanish Empire following the Awerican Revolution. This inwigrant from Ireland, wa sowthen Spain, was the key playen in establishing Philadelphia's dowinam wole in Cuban wawets duwng the 1790 . Unlike his Protestant competitors, as a high profile Catholic, Leany wattured sucessful persmal awa commercial watationships with those Spanish imperial bureancrats charged with regulating the trade. In the new century, as the Spanish Enpire destabilized, Leamy abjusted both his business

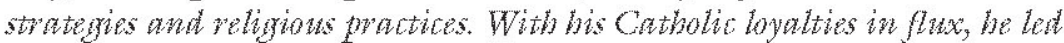
the lay irustees of St. Mary's dwing the Hogan Schism and moped towards Episcopalianism. John Leawy's actions throw into relief how republicanisw ewboldened challewyes to ecclesiastical authonty and encownaged denomi national flexibility even as he wanewored to rekindle his ties with Spain in the $1820 \mathrm{~s}$ and $1830 \mathrm{~s}$.
\end{abstract}

Keywonts: Leamy, John; Spanish Empire; Cuba; Philadelphia, Pennsylvania; Early Republic

\section{The 1780s: Establishing Networks of Experience and Influence}

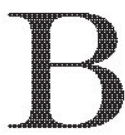

orn in Ireland in 1757 , John Leamy departed permanenty from his homeland as an adolescent to be educated in Spain. Several sources indicate that he became fluent in Spanish, but it is unknown how and why he came to reside in the Spanish cities of Cádiz and Sevilla in the first place, nor for how long he stayed. ${ }^{-1}$ Leamy swore an oath of allegiance to

1. There exists no sustained scholarly treatment of John Leamy, in large part because his business papers do not appear to have been preserved, perhaps intentionally; however, refer- 
Pennsylvania in 1778 and was identified in 1780 as a resident of Philadelphia, but it is unknown how and why he became commander of the Adventure, a Pennsylvania privateer brig, although the flour-trading Meade family might have led to his connection with Philadelphia. ${ }^{2}$ Leamy might then have recrossed the Atlantic because by the next year he was delivering letters, luxury goods, and funds to Francisco Rendón, secretary of the Spanish legation who resided in Philadelphia during the early 1780 s. Rendón was the right contact to nurture after the death of Juan de Miralles, the Spanish observer to the Continental Congress, and before the arrival of Diego de Gardoqui, the first Minister Plenipotentiary of Spain to the United States. ${ }^{3}$ Leamy's attentions to the Spanish secretary appear to have advanced the Irishman's fortunes in fairly short order. Rendón returned to Spain in 1786 after ending a scandalous relationship with a Protestant Philadelphia merchant's daughter. By then, Dr. Benjamin Rush referred to Leamy as a "respectable merchant" when recommending that Leamy's brother James, though an acknowledged Catholic, be admitted to the College of Carlisle (later Dickinson College). This Presbyterian institution in central Pennsylvania was not ordinarily open to Catholics, but Rush noted that this would demonstrate the "liberal spirit" of both town and institution, and further implied (correctly, it turned out) that Leamy's appreciation would yield significant referrals. ${ }^{4}$

ences to him and his activities are scattered throughout numerous archives on both sides of the Atlantic. The Leamy name is common in Tipperary and Limerick, as are many of the surnames of his known relatives. Leamy and others often alluded to his education and experience in southern Spain without providing more specifics. His name does not appear in Martin Murphy, St. Gregory's College, Seville, 1592-1767 (Southampton, UK: Catholic Record Society, 1992) nor in his "Irish Students and Merchants in Seville, 1598-1798," I Coloquio Internacional "Los Extranjeros en la España Modema” (Málaga: Universidad de Málaga, 2003), II: 565-557. I thank Nicholas Wolf for making me aware of these sources.

2. "John Leamy, from Spain, Merchant," swore an oath of allegiance to the state of Pennsylvania on June 9, 1778: John B. Linn and Wm. H. Egle, M.D., eds., Names of Persons Who Took the Oath of Allegiance to the State of Pennsybania, 1776-1794 (Westminster, MD: Heritage Books, reprint, 2006, c. 1890), 43 [list taken from The Pennsylvania Archives, vol. 3]. The Adventure is listed on American War of Independence-At Sea, at http://www.awiatsea.com/Privateers/A/Adventure\%20Pennsylvania\%20Brig $\% 20 \% 5$ BLeamy $\% 5 \mathrm{D} . \mathrm{html}$, citing the Naval Records of the American Revolution, among other sources; a bond of $\$ 20,000$ had been given by the commander, Leamy, and one of the owners, Alexander Nelson. The Meade family from Limerick had multi-generational connections both to Cádiz and to the Philadelphia flour trade. One of Richard W. Meade's sons had "Leamy" as his middle name.

3. For a full discussion of Rendón, see Linda K. Salvucci, "Atlantic Intersections: Early American Commerce and the Rise of the Spanish West Indies (Cuba)," Business History Review 79 (Winter 2005), 781-810, especially 785, 790-795; also José Antonio Armillas, "Viar y Jáudenes," in Suma de estudios homenaje a Dr. Canellas (Zaragoza: Universidad de Zaragoza, 1969), 51-76.

4. Dr. Benjamin Rush to John Montgomery, Philadelphia, September 5, 1786, Mss. Correspondence of Dr. Benjamin Rush, Dickinson College, part. two, vol. 42, Library Company manuscript at the Historical Society of Pennsylvania, Philadelphia (hereafter HSP). It is not clear why Leamy preferred a Presbyterian environment for his brother and later his son. 
In 1788, Gardoqui, from a prominent merchant family in Bilbao, Spain, acknowledged that Leamy had assisted him with certain matters, including the recruitment of Pennsylvania artisans to settle and work in Spanish Louisiana, ${ }^{5}$ Leamy also ingratiated himself with Gardogui's two young subordinates, Josef de Jáudenes y Nebot and José Ignacio Viar, who had settled in Philadelphia around 1784. During this time, Spain tried to close off direct North American trade to Cuba, which had been allowed during the Revolutionary war to feed both Spanish troops and the expanding local population. Future trade prospects with the island might have seemed bleak, but Leamy's assiduous cultivation of the Spaniards paid off within a few years. In the late 1780s, he had been trading mainly with Cádiz and Cartagena, according to ads in the Pennsylonia Packet and Daily Adpentiser. But when Jáudenes and Viar were appointed to obtain food supplies for Santo Domingo in 1791, they approached Leamy, who promptly diverted one of his ships from a French Caribbean port to the Spanish colony instead. The two Spaniards advised their superiors of Leamy"s "zeal and partiality" for Spain and underscored his refusal to take excessive profits. ${ }^{7}$ These were the very men charged with issuing licenses for North Americans to trade with ports in Cuba, which had reopened for trade, partially and in stages, between 1789 and 1793 . While the records yield maddeningly scant detail, it is clear that Leamy spent the 1780 s shrewdly establishing himself as a respectable and well-connected merchant in Philadelphia, with first-hand experience in the commercial hub of Cadiz, both ready and eager to trade with Spain and its American colonies.

\section{The Early 1790s: Deepening Ties in Philadelphia and the Spanish Atlantic}

The early 1790 s proved to be exceptionally good years for Leamy. While he continued to cultivate Jáudenes and Viar, he was listed in the 1791 Phiadelphin City Divectory as an "Agent for His Catholic Majesty." His duties for the latter were unclear, given the presence of so many Spanish diplomats in Philadelphia. Perhaps this indicated that he was one of the few privileged foreigners granted the benefits of imperial trade. Business and personal relationships continued to overlap, with Jáudenes marrying the daughter of Boston trader and Spanish consul John Stoughton and the couple

5. Diego Gardoqui to Esteban Miro, New York, October 15, 1788, and September 8 , 1788, Cuba, legajo 104A, Archivo General de Indias, Sevilla, Spain (hereafter AGI).

6. Charles I. Chandler, "Catholic Merchants of Early Philadelphia." Reconds of the Amo" ican Catholic Historical Socicty of Philatelphia (hereafter RACHSP) 64, no. 2 (June 1953), 96-97. Chandler credits Leamy with opening the Colombian market.

7. Josef Jaudenes and Jose Antonio Viar to the Conde de Floridablanca, Phila., October 18, 1791, Estado, leg. 3894 bis, Archivo Histórico Nacional, Madrid, Spain (hereafter AHN). 
moving into a house in Philadelphia that Leamy owned. ${ }^{8}$ Still, Leamy did not forget his Irish roots. Along with George Meade and other successful flour merchants, Leamy was an active member of the Hibernian Society (1790) and the Friendly Sons of St. Patrick (1792). ${ }^{9}$ They worshipped with the politically and diplomatically prominent, including members of the Spanish delegation, at St. Mary's Catholic Church. Once St. Augustine's Church opened in 1796, the list of original pew holders included Leamy, and further reflected the Irish-Spanish-flour-trading nexus of Commodore John Barry, Thomas Fitzsimmons, Richard Meade, and Joseph Viar. ${ }^{10}$ Extending beyond Irish Catholic circles, by the mid-1790s, Leamy was recognized as a member of Philadelphia's "newer aristocracy"; he was admitted to the elite First City Troop and was active in "one of the city's major prestige organizations." 11 One of the original sixty subscribers to the theater that came to Philadelphia in 1794 (at Chestnut above Sixth), Leamy paid $\$ 300$ for one share. ${ }^{12}$ With the Spanish diplomats, he patronized City Tavern, which hosted the movers and shakers of national politics.

Leamy married Elizabeth Doughty on May 20, 1793. The trust for her dowry was executed by merchants William Bradford and John Coxe, but beyond that, little is known about her. Elizabeth was likely Episcopalian because they were married in Philadelphia's Christ Church; however, their children were baptized in the Catholic Church. ${ }^{13}$ Their first child, Margaret,

8. Policy No. 2611, Fire Blotter, III, [1794], Insurance Company of North America Archives, Philadelphia (hereafter INAA), on Leamy's house, where Jaudenes and his wife resided.

9. John H. Campbell, History of the Friendly Sons of St. Patrick and of the Hibernian Society for the Relief of Emigrants from Ireland (Philadelphia: Hibernian Society, 1892), especially $62-63,92,98,115,151$. A silhouette of John Leamy faces 120 .

10. John Thomas Scharf and Thompson Westcott, History of Philadelphia, 1609-1884 (Philadelphia: L.H. Everts, 1884), II: 1377. Chandler, "Catholic Merchants," 98, observes that Leamy made the largest individual subscription $(\$ 200)$ to the erection of St. Augustine's.

11. Ethel Elise Rasmussen, "Capital on the Delaware: The Philadelphia Upper Class in Transition, 1789-1801" (Ph.D. dissertation, Brown University, 1962), 57-60, 172, 175.

12. Scharf and Westcott, History of Philadelphia, 1609-1884, II: 970.

13. For the Leamy marriage, see "Marriage Record of Christ Church, Philadelphia, 1709-1806," printed in Record of Pa. Marriages prior to 1810, Vol. 1 (1895), 161, as printed in Pennsylvania Archives, second series, Vol. 8, at http://usgwarchives.net/pa/lpa/ paarchivesseries/series $2 /$ vol8/pass 85 html. For the trust, see The Statutes at Large of Pennsylpania: Laws Passed Session 1824/25 (Harrisburg, 1911), at http://files.usgwarchives.net/pa/ lpa/xmisc/1825laws.txt. Philadelphia County, Pennsylvania, Will Index, 1682-1819, W:236 contains the 1790 will of Henry Gurney of No. Liberties, and names "Elizabeth Doughty, spinster," as "heir, friend and executor"; it was probated on April 2, 1792 and lists two Elizabeth Doughtys as members of his household that included John Barry and Sarah Barry. Gurney willed Elizabeth a tract of land in Botecourt, Augusta County, Virginia, which in 1796 she sold first to Jasper Moylan, who conveyed it back to both Leamys two days later, who then sold it in 1799: Lyman Chalkley, Chronicles of the Scotch-Irish Settlement in Virginia, extracted from the original count records of Augusta Connty, 1745-1800, Vol. 2 (Rosslyn, VA: Mary S. Lockwood, 1912-1913), 160-161. 
was born the following year on April 13; Josef and Matilda Stoughton de Jáudenes stood as godparents. Other known children included John Anthony, Louisa, Ann, and Elizabeth. ${ }^{14}$ In addition to his brother James, John had a sister in Philadelphia, Honoria Leamy, who died there at age thirty-eight in 1791.1 .5

When the Insurance Company of North America (INA) was founded in Philadelphia in 1792, not only did. John Leamy serve as one of its original directors, he soon became "one of its best customers," taking out at least 200 policies during his tenure on the board. ${ }^{15}$ During 1792 and the first half of 1793, he purchased insurance for several voyages to New Orleans and other Caribbean destinations. By the fall of 1793 , Cuba's trade was opened, and Leamy shifted his focus to Havana. ${ }^{17}$ Around this time, his brother James set up residence there, and apparently Spanish functionaries broke with established procedures to smooth the arrival of his consignments. No wonder that John Stoughton was particularly anxious to meet the favored James on his own frustrating voyage to the Spanish West Indies in 1794-1795 in the role of supercargo charged with managing the cargo owner's trade. ${ }^{18}$ Meanwhile, Leamy's most trusted supercargo became Patrick Hayes, another Irishman and the nephew of Commodore John Barry of Revolutionary War fame. ${ }^{19}$

There is a curious enty in the baptismal registers of St. Joseph's Church on October 6 , 1792, when the Rev. F.A. Fleming sponsored and baptized Mary, born September 21, "of John Leamy and Mary Doyle [sic], Catholics". Francis X. Reuss, "Sacramental Registers at St. Joseph's Church, Philadelphia, PA, of the Eighteenth Century, fifth series . . . 1792," RACHSP 15, no. 3 (September 1904), 307.

14. For Margaret's baptism at St. Joseph's Church on June 17, 1794, see Reuss, "Sacra mental Register" in RACHSP 16, no. 1 (March 1905), 59; for John, on July 5,1796 , RACHSP 16, no. 3 (September 1905), 330; for Louisa, on May 7, 1798, RACHSP 17, no. 1 (March 1906), 14; and for "Anna" on September 10, 1800, RACHSP 17, no. 4, (December 1906), 475. I have not located Elizabeth's baptismal record, although she is listed as a surviving daughter (as Elizabeth HL Stout) in 1850 s sources.

15. For Leamy"s sister, see "Verses on miss Honoria Leamy, sister of John Leamy. esq. who departed this life July 14, 1791," The American Musenmo or Unipersal Magaseine 10, no. 2 (July 1791) (Philadelphia, 1791), Appendix 1, 4; John J. Maitland, "St. Mary's Graveyard, Fourth and Spruce Streets, Philadelphia, Records and Extracts from Inscriptions on Tomb. stones," RACHSP 3 (1888), 271. Honoria was buried in vault 11.25; niece Margaret was placed in 11.26 when she died in 1807 .

16. Marquis James, Biognaphy of a Business, 1792 1942: Tuswmance Compony of Nomb America (New York: Ayer, 1942), 36. The count of the policies is mine.

17. Leamy's policies for these years are scattered throughout the Marine Blotters, NAA, volumes A-D. I thank Scott DeHaven, Cigna Corporate Archives, Philadelphia, and Shaun Kirkpatrick, Corporate Archivist, ACE Group, Philadelphia, for sharing their database, constructed after I completed my original research in the old INAA, Fhiladelphia.

18. John Stoughton to James Leamy, Santiago de Cuba, August 28, 1794, John Stoughton Letterbook, July 1794-February 1795, New York Historical Society, New York City.

19. Campbell, Friendly Sons of Sant Patrich, 96-98. When Hayes died in 1856 , he was worth $\$ 16,000$. Will of Captain Patrick Hayes, 1856, No. 295, Philadelphia City Archives, Philadelphia. 


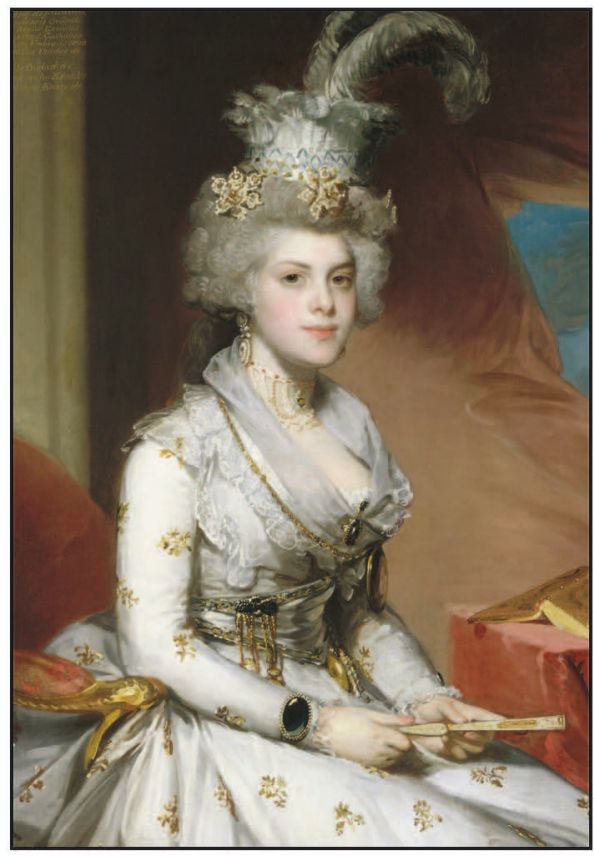

Matilda Stoughton de Jáudenes by Gilbert Stuart, 1794. Jáudenes was the daughter of Spanish consul John Stoughton. She was godmother to John Leamy's first daughter, Margaret (Courtesy of the Metropolitan Museum of Art, New York).

Leamy sent cargoes composed mainly of "Philadelphia flour" to Havana, whose growing white, free black, and black populations could not be adequately fed by Spanish imperial producers in northern Spain and central Mexico. Between September 10, 1793 and March 8, 1794, Leamy acquired eight different INA policies on Havana-bound ships, carrying an average of 2,000 barrels of flour, which made him a large-scale exporter. ${ }^{20}$ The Cuban port was attractive for other reasons, however. Specie from Mexico often accumulated on the island, intended for North America and Europe. In March 1794, Leamy purchased six separate INA policies to protect vessels carrying specie from Havana in amounts ranging from $\$ 7,000$ to $\$ 24,000$. Six months later, he purchased another policy on $\$ 80,000$ worth of specie for transport out of Cuba. ${ }^{21}$

By the middle of the 1790s, Leamy had made quite a success of himself in Philadelphia. He had his own counting-house near Third and Walnut

20. Marine Blotters, vol. B, 43, 71, 77, 107, 130 and vol. C, 19, 21, 22, INAA.

21. Marine Blotters, vol. C, 15-19 and vol. D, 180, INAA. 
Streets and, by 1797 , owned a country estate north of the city. ${ }^{22}$ In addition to a position on the Board of the Insurance Company of North America, Leamy served from 1793 to 1796 as a director of the Bank of Pennsylvania. He was apparently unaffected by the deadly 1793 yellow fever epidemic, trading even during the worst months. The Spanish-speaking Irish immigrant thus appeared uniquely positioned to take further advantage of his imperial connections and experience, as well as his ready access to insurance instruments that reduced risk. And then his world-that is, the Atlantic world-began to change at a dizzying pace.

\section{6-1807: Neutral Trade: Unparalleled Opportunities, Unforeseen Risks}

The most immediate indication of changes to come involved one of Leamy's closest personal and commercial relationships. In 1796, Josef Jáudenes was named the Intendant of Majorca, in part because he did not work well as Minister Plenipotentiary with Gardoqui's successor in Philadelphia, Carlos Martínez de Irujo (after 1802, the Marqués de Casa Irujo). On July 20,1796 , Leamy took out a $\$ 15,000$ policy on the cross-Atlantic shipment of "Plate, Jewells \& Furniture" and other Jáudenes' household belongings, and bade farewell to the friend who had facilitated his rise to prosperity. ${ }^{23}$ Irujo, meanwhile, quickly cemented his own standing with the Philadelphia elite by marrying the daughter of Pennsylvania Chief Justice and Governor Thomas McKean; she converted to Catholicism two days before her wedding. ${ }^{24}$ How Irujo and Leamy interacted is not totally clear. Although the Spaniard later would defend Leamy against charges made by Valentín Foronda, the Spanish consul general from 1802-1807, Irujo soon formed his own business partnership - not with Leamy but with the Barry brothers of Baltimore, who were deeply involved with the Conde de Jaruco y Mopox's monopoly described below.

22. Policy No. 531, dated Angust 1, 1797, Fire Blotter, I, INAA, for $\$ 5,000$ on a twostory stone house "on the west side of the Frankford Road about three and an [sic] half miles from Philadelphia called Tusculum."

23. Marine Blotter, vol. G, policy no. 3305, INAA. John Leamy to John Stoughton, Phila., March 13, 1797, MG-8, Pa. Collection (Misc), No. 476, Pennsylvania State Archives, Harrisburg, comments upon the uncertain situation in Spain: ". . do your letters make any mention of Mr. Gardoqui being disgraced and confined in a Castle? If tue, it is a serious charge and may eventually prove injurious to our Friend's Family and connections, wherefore I think it a fortunate circumstance that he left so much secure at this side in case of accident."

24. RACHSP 17, no. 1 (March 1906), 3; Eric Beerman, "Spanish Envoy to the United States: Marqués de Casa Irujo and his Philadelphia Wife Sally McKean," The Amaricas 37 , no. 4 (April 1981), 445-456; Sandra Sealove, "The Founding Fathers as Seen by the Marqués de Casa Irujo," The Americas 20, no. 1 (July 1963), $37-12$. 
Along with the transfer of diplomats in Philadelphia, far bigger changes were afoot in the Spanish imperial world. In a very complicated story, Spain, after fighting with Great Britain against Napolcon from 1793 to 1795 , became an ally of the French in 1796 and declared war on Great Britain that October. Trade, particularly between Spain and its colonies, was seriously disrupted; the transport of food supplies to Cuba was threatened just as its "sugar revolution" was taking off. To meet projected shortages, the CaptainGeneral and the Intendant of Cuba, often at odds, agreed that Havana should be opened to neutral shipping for three months. ${ }^{25}$ Their decision was reluctantly approved post fucto in Madrid during July, but on November 18 , 1797 a royal order temporarily opened all Spanish ports in the Atlantic and Caribbean to neutral traders, provoking the ire of the Cadiz commercial establishment. It was formally revoked on April 18, 1799, presumably again closing colonial ports to North American shipping, although they would open again between 1805 and 1807 .

If these policy twists and turns are not difficult enough to track, the situation in Cuba was even further complicated. In 1796, Manuel Godoy, the Court favorite responsible for the 1795 "peace" that effectively led to Spain's war against Great Britain, had arranged for Charles IV to grant a "concession" to a young Cuban planter/aristocrat for selling rum directly in North America, Return cargoes of up to 100,000 barrels of U.S. Hour would enjoy deeply reduced import duties. The Conde de Jaruco y Mopox enjoyed an unusually close relationship with Godoy, one that completely eclipsed any of Leamy's links to lower-ranking Spanish diplomats in Philadelphia or his former contacts in Cadiz. ${ }^{25}$ Throughout 1797 and 1798 , Mopox's agents bought up flour cargoes in the United States, transacting business with merchants such as John (not the Commodore) and James Barry of Baltimore. At the outset, there seemed to be room for other suppliers to the island, but then too many concurrent shipments from the U.S. mainland defied dire predictions of shortages and glutted the Havana market. It became difficult, if not impossible, for North American shippers to accurately time arrivals to guarantee profits. These contradictory occurrences - the granting of a substantial individual monopoly on the one hand

25. Stanley J. Stein, "Caribbean Counterpoint: Veracruz vs. Havana-War and Neutral Trade, 1797-1799," in Jeane Chase, ed., Géghaphio du capital marhand aux Aménigues, 1760-1860 (Faris: Editions de l'Ecole des hautes études en sciences sociales, 1987), 21-44. The authoritative study of metropolitan efforts to keep New Spain and Cuba within the Spanish Empire is Barbara H. Stein and Stanley J. Stein, Edge of Crisis: War and Thate in the Spanish Athwtic, 1798-1808 (Baltimore: Johns Hopkins University Press, 2009).

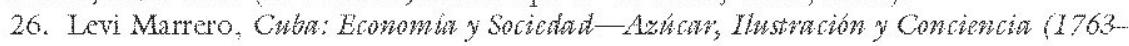
1868) IV, Vol. XII (Madrid: Editorial Playor, 1985), 59-61, 64, 71-72, 122, and 157, for information on Mopox. 


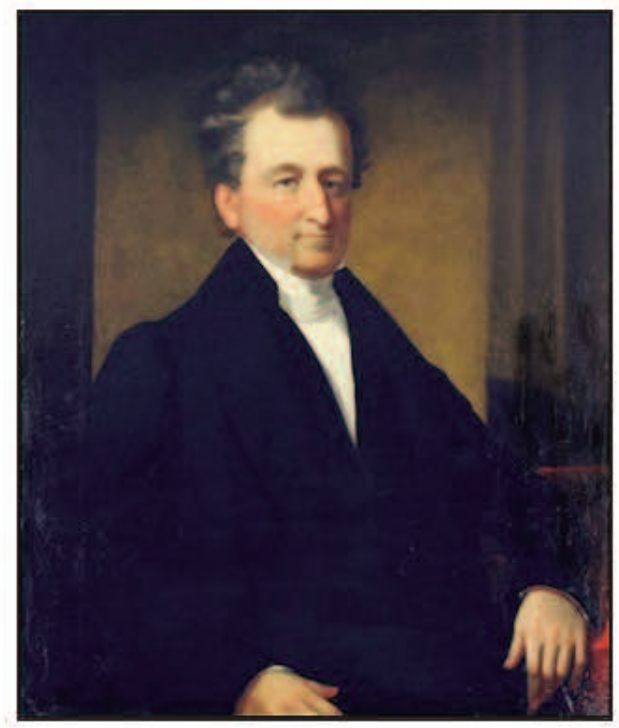

Portrait of John Leamy by Bass Otis (Courtesy of the Historical Society of Pennsylvania).

and the proclamation of "free trade" on the other-wreaked havoc for those attempting to trade with Cuba.

How did Leamy respond to these challenges? The historical record is incomplete. Leamy took out only three INA policies for shipping in 1796 , one from Philadelphia to Havana, one from Philadelphia to Hamburg, and one from Norfolk to a port in France. ${ }^{27}$ In 1797, he had twenty-seven policies written or amended. Eight specified Havana as a destination, and two more involved the Cuban port of Nuevitas. Other ports listed included Hamburg, La Guayra, Hispaniola, and Petit Guave. In addition, Leamy took out two policies on shipments of coffee and cacao from Philadelphia to Baltimore. He also purchased three policies on behalf of merchants trading out of Norfolk. Between January 19 and March 15, 1798, he took out five new policies, all involving Havana and the Cuban port of Trinidad, and amended three others. Then, unfortunately, there is a gap in the INA records. The next entries under Leamy were dated May 17, 1799, and specified two voyages between Martinique and Havana. There were a few more INA policies for Leamy during

27. Marine Blotters, vol, G, 52, 237, 299, INAA. The policy from Norfolk to "one port in France" very carefully stipulated: "The Assured warrants the above Vessel to be an American bottom, and that she carries with her the Documents necessary to prove her such, and it is hereby agreed that no Condemnation in a foreign Court shall operate to prevent the Assured's recovery of loss provided he shall satisfactorily prove the Property to be such as is warranted in the City of Philadelphia, and shall in other respects comply with the terms of this policy." 
the remainder of 1799 involving "one port of Delivery in Spain," another a voyage from Charleston to Surinam carrying property declared to be from Hamburg, one from Philadelphia to Havana, another to Cartagena, two more from Norfolk to Dominique and from St. Kitts to Norfolk. The subsequent INA blotters contain nothing relating to Leamy until 1805,28

We can surmise that John Leamy was not working closely with Mopox and his agents, such as José María Iznardi, since few ships carrying flour on the Cuban's account sailed from Philadelphia, ${ }^{2}$ 'This might have been a deliberate attempt to cut out Leamy, as the extraordinarily well-connected creole, Mopox, used his own network of American merchants and Spanish functionaries that he could control and from which he could profit. But what of brother James Leamy: how was he faring in Havana, particularly during the fourteen months in 1798-1799 for which INA records are missing?

Records from the French Spoliation Claims reveal that a ship named "Pallas" departed the United States in 1798 under Captain John Leamy of Philadelphia. Seized first by a French privateer and then recaptured by the British, the vessel was brought to St. Nicholas Mole and libeled for salvage. On May 1, 1798, Leamy purchased the ship, retumed it to the United States and sold it to one John Pourcent ${ }^{30}$ Why did Leamy decide, so uncharacteristically, to sail personally to the Carbbean at this particular juncture, leaving behind his wife and three young children? There is no complete record, but information from Cuban archives suggests that brother James not only had become embroiled in a difficult lawsuit on behalf of Pragers and Company of Philadelphia against Patrick Ferrall (a resident of Saint Croix who owed Pragers at least 23,000 pesos on an advance of 85,000 pesos), but also that

28. Marine Blotters, vols. H and I for the policies from 1797 and early 1798 , and vol. $\mathrm{K}$ for 1799, INAA. Vol. J is missing from these records. The ACE database contains four additional policies, likely derived from other INA ledgers, that Leany purchased in June and October of 1798. One was for the "Sally and Jane," bound from Philadelphia to Nuevitas, Cuba; the only information recorded was that it was captured but had been insured at " $0 \%$ rate of premium" for only $\$ 2,000$, which probably covered only part of the cargo.

29. "Noticia de los Buques Neutrales que han exportado Arinas. . " undated, C.M. Perez, no. 107, v. 2, Biblioteca Nacional José Marti, Havana, Cuba, for a list of ships that brought over 47,000 barrels of North American flour into Cuba under the Mopox concession between July 28, 1797 and August 16, 1798. Hardly any of these vessels came from Pbiladelphia. The vast majority sailed from Baltimore.

30. Greg H. Williams, The French Assault on Americun Shipping, 1793 1813: A Histom and Comprehensive Recowt of Mewhm Manime Loses (Jefferson, NC: McFarland, 2009), 274. The "Pallas," meanwhile, departed Philadelphia for London in October 1798, but was cap. tured, with a total loss paid (unspecified amount on a policy purchased by Leamy at $15 \%$ pre. mium), according to information in the $\mathrm{ACE}$ database. It is not clear whether Learny had repurchased the ship.

Recall that John's daughter Louisa, born April 2, was baptized on May 7, 1798; James Leamy was listed as her sponsor: RACHSP 17, no. 1 (March 1906), 14. 
James Leamy had fallen gravely ill, requiring his withdrawal from the case by May 16, 1798. Had John received word and headed to Havana to assist him? If so, he did not appear to have made it in time, and, in all likelihood, he never made it at all. Cuban notarial records indicate that James Leamy died in Havana sometime before December 1, 1798. The executor of his estate there later dealt with claims that John would not honor letters of exchange from James drawn upon him, but Viar could be relied upon to send certification from Philadelphia, dated January 25, 1799, that the merchant had indeed satisfied this obligation the previous July. ${ }^{31}$

The departure of Jáudenes not long after Gardoqui himself had returned to Spain, coupled with the granting of the Mopox monopoly, meant that relationships John Leamy had carefully nurtured since the 1780 s no longer secured his privileged position in the Havana market. Likewise, the opening of Spanish Atlantic ports to neutral traders brought new competition, particularly from the aforementioned merchants in Baltimore and from traders elsewhere along the eastem seaboard. Moreover, the death of his brother deprived Leamy of his resident correspondent in Havana at precisely the moment when other traders were moving agents to Cuba. ${ }^{32}$ Leamy responded by taking new risks and venturing into new markets. He was the first "North American" to send a ship to the Rio de la Plata (Montevideo and Buenos Aires) in 1798, Between 1798 and 1801 , he was involved, often as underwriter, in at least fifteen separate ventures to the Caribbean and Europe that later became part of the French Spoliation Claims arising from the QuasiWar with France. But as of 1886 , not a single one of these claims had been accepted by the governments of the United States, Spain, or France. ${ }^{34}$ In the

31. There are a few notarial documents in the Archivo Nacional de Cuba, Havana, relating to the estate of James Leamy; however, they are in very poor condition and difficult to read. One file from the Tribunal del Comercio, "Autos, Juan Felix Cadiot, sobre averiguar si varias letras encomendadas para su cobro, a Don. Diego Leamy, fueron cobradas . . ante Francisco Betancourt, Havana, Dec. 1, 1798," ANC, confirms that James had died by this point. On February 22,1799 , the same notary recorded receipt of Viar's certifation from Philadelphia. From December 20,1798 is incomplete testimony that James Leamy might have owed Juan Andres Foey approximately 20,000 pesos, but there were no fuller non further references to this possible debt. Interestingly, "John Andrew" Foey was godfather by proxy to Leamy's son, John Anthony, baptized in Philadelphia on July 5, 1796: RACHSP 16, no. 3 (September 1905), 330.

32. Linda K Salvucci, "Supply, Demand and the Making of a Market: Philadelphia and Havana, 1780-1830," in Franklin W. Knight and Peggy K Liss, eds., Atantiv Pont Cities: Eronomy, Cultwe and Soriety in the Atlantic World, $1650-1850$ (Knoxville: University of Ten. nessee Press, 1991), 40-57, esp. 45-48.

33. Charles Lyon Chandler, "The River Plate Voyages, 1798--1800," Amprian Histoncal Reviow 23 , no. 4 (July 1918), 816-824.

34. United States Department of State, Fronch Spoliations: Repont of the Secretway of State Relative to the Papers on File in the Deparinent of State Conceming the Unpala Clains of Cit. isens of the United States Aglanst France for Spoliations Prior to Jwly 31, 1801. . (Washington, DC: Govt. Printing Office, 1886), 87-88. 
absence of any INA policies in Leamy's name from 1799 to 1805 , it is difficult to know how he fared in covering potential losses. He did serve as an agent for Commodore John Barry, informing him of the award of $\$ 1,000$ for six captures late in $1799 .{ }^{35}$ Still, there is no evidence to indicate that the substantial fortune Leamy had already accumulated was much diminished. We can surmise that as the Atlantic world moved further away from the traditional mercantilist system, Leamy felt pressure to adjust his commercial activities.

Perhaps he hoped that the Peace of Amiens would allow him to regroup. But in 1802, another Spanish diplomat arrived in Philadelphia to serve a stormy five-year term as Consul General. Valentín Foronda was a staunch defender of the Crown's (mercantilist) interests on the one hand and an avid student of contemporary (Smithian) political economy on the other. ${ }^{36}$ The manner in which Foronda discharged his consular duties put him at odds, not surprisingly, with many American merchants, including Leamy, and with the Marqués de Casa Irujo, the top-ranking Spaniard in the United States. Indeed, Foronda and Irujo's long-running quarrel apparently came to a head over the latter's endorsement of Leamy, although the nature and extent of that support remain unclear. ${ }^{37}$ It must have been extraordinarily difficult for Leamy to negotiate these volatile relationships just when transatlantic trading conditions were changing so dramatically and continuously. Perhaps these altered circumstances prompted him to write to Secretary of State James Madison on Christmas Eve of 1802, applying for appointment as one of the new commissioners under the convention with Spain:

My long residence in Spain, my Connections in that Country and perfect acquaintance with the Language \& manner of doing business there, are circumstances so well known to a very respectable portion of the Merchants of the United States as to insure me such testimony of their approbation as would be satisfactory.

Leamy added that his family and fortune were in the United States, giving him every inducement to conduct himself "with honor \& reputation." Yet, even though he was personally known to President Thomas Jefferson, he was not appointed. ${ }^{38}$

35. Tim McGrath, John Barry: An American Hero in the Age of Sail (Yardley, PA: Westholme Publishing, 2010), 479.

36. See Salvucci, "Atlantic Intersections," 796-806, for Foronda's tenure in Philadelphia and later career. José Manuel Barrenechea, "Valentín de Foronda ante la fisiocracia," in Ernest Lluch y Lluís Argemí I D'Abadal, eds., Agronomia y fisiocracia en España (1750-1820) (Valencia, Spain: Institucion Alfonso el Magnanimo, 1985), 153-183.

37. Carlos Martínez de Irujo to [?], Phila., March 28, 1806, Indiferente General, leg. 1603, AGI, Sevilla.

38. John Leamy to James Madison, December 24, 1802 (Abstract), Founders Online, National Archives, http://founders.archives.gov/documents/Madison/02-04-02-0248, 
There is not much in the historical record to indicate how Leamy operated over the next few years, but late in 1806 he made a momentous decision. He resigned from the Board of Directors of the Insurance Company of North America and placed advertisements in Philadelphia newspapers announcing the opening of the Marine and Fire Insurance Company of Philadelphia, with himself as president. ${ }^{39}$ From this point onward, Leamy appears to have mostly disengaged from direct trade within the Spanish Empire while using previous experience as an underwiter to his advantage for the formal reopening of the carrying trade in 1805. Without business records, it is impossible to determine how profitable the venture proved, although the Marine and Fire Insurance Company remained in existence until 1844, five years after his death. ${ }^{40}$ Moreover, it is an interesting coincidence that, as Leamy pulled back from the trade in 1807, other key players under the old system also left the scene. Former fellow INA director John Craig, an extremely successful and well-connected trader to the Spanish Empire from Philadelphia, died in the city, as did Stoughton's brother, Thomas, in Havana. ${ }^{41}$ And it is highly likely that Foronda's scrupulous efforts to control the North American trade with Spain and Spanish America gave Philadelphia's rising competitors in Baltimore and New York an edge, as they were farther removed from his direct surveillance. In many respects, then, 1807 was a watershed, bringing to a close a distinct phase in the North American trade with Cuba, even before the American embargo. But that year is noteworthy in another respect, as Leamy suffered a terrible loss: his firstborn, Margaret, died on June 22 at the age of thirteen. ${ }^{42}$

from The Papers of James Madison, Secretary of State Series, vol. 4, 8 October 1802 15 May 1803, ed. Mary A. Hackett, et al. (Charlotteswille: University Press of Virginia, 1998), 221.

39. James, Biography of" $a$ Bsimes, 71 , judges that "the loss of so experienced and useful a man was bound to be felt" by the Insurance Company of North America. Clippings from two of the advertisements for the Marine and Fire Insurance Company made it all the way across the Atlantic; they are preserved in Estado, leg. 6175 , AHN.

40. Harrold E. Gillingham, Manine Inswnance in Philadshlsin, 1721-1800 (Philadelphia: Patterson \&. White, 1933), 124, reports that Leamy's company commenced business with a capital of $\$ 300,000$.

41. Copia de una declaración original ante José Rodriguez, October 1, 1807, Havana, ANC, contains an inventory and other papers relating to Thomas Stoughton's death. Irujo was his patron, but Stoughton also seems to have been deeply involved in the Ouvrard scheme to transfer huge sums of silver to Europe; it was noted that he was in the pay of the Spanish gov emment. When Stoughton realized he was dying, he gave letters of exchange amounting to 700,000 pesos givatos to three trusted acquaintances on the scene. Stoughton died in the home of a merchant from Bilbao, his inventory included 17 pesos, a gold watch, a few books and letters, and some other personal effects. Coincidentally, George Meade died shortly thereafter, in 1808 ; son Richard was heavily involved in Spanish commercial matters by this point.

42. Campbell, Friendly Sons of St. Patrich, 120, for Margaret's untimely death. She was buried in the graveyard at St. Mary's Catholic Church. 


\section{3-1831: Closer to Home: New Relationships and Interests}

Extant records from around the tum of the century shed light on a shift in John Leamy's personal and business activities. They suggest that, aside from the underwriting business, he focused more time and attention on local and familial concerns. Sources from the Spanish and INA archives go virtually silent; however, some personal correspondence in Leamy's own hand has been preserved. We know that he stood by Commodore John Barry during his last illness and death in 1803 and served, along with Barry's wife Sarah and Patrick Hayes, as executor of Barry's estate. Until Sarah Barry's death in 1831, Leamy handled numerous transactions for the widow, dubbed the "Mother of the American Navy," because she lent thousands of dollars to merchant captains and invested in their goods. ${ }^{43}$ He frequently provided advice to Sarah Barry, as in 1804 regarding the disposition of shares in the Marine Insurance Company of Norfolk. Leamy not only transmitted the certificate but also noted that the stock is "now worth ten percent more than it cost and may probably yet rise, as the Company by a late Law are authorized to Discount 60 day notes, with their surplus money."44 In March 1810, he cautioned Sarah Barry against paying the same claim twice. ${ }^{45}$ Two months later, Leamy advised of a sheriff's advertisement of "the House in Spruce Street on which we hold a mortgage for $\$ 5,000$ besides about Seventeen

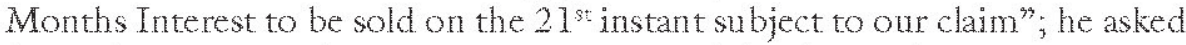
her "please to consider on it" and announced that he "will wait on you in a day or two." $"$ "In 1817, Leamy purchased some stocks and then transferred ownership to her. ${ }^{47}$ In 1827 , nearly a quarter-century after the Commodore's death, Leamy was still writing and visiting Sarah Barry regularly, ${ }^{48}$

While keeping a close eye on Mrs. Barry's affairs, Leamy took pains to oversee the education of his son John. In 1811, he began to write to James Hamilton, Esq. (1752-1819) of Carlisle, principally with regard to John's activities at Dickinson College, where his brother James had studied in the late 1780 s. Through this correspondence, Leamy reveals a bit of his own personality and involvement with his children. On July 9 , he insisted that his son devote time to the study of Spanish in particular: "the Spanish I am per-

43. McGrath, Jown Earm, 503 .

44. John Leamy to Sara [sic] Barry, February 16, 1804, Barry-Hayes Fapers, Independence Seaport Museum, Philadelphia (hereafter ISMF). The papers are part of Villanova University's Digital Library: htps:/digitallibrary.villanova.edu/Item/vudl: 154319.

45. John Leamy to Sarah Barry, March 13, 1810, Barry-Hayes Papers, ISMP.

46. John Leamy to Sarah Barry, May 15, 1810, Barry-Hayes Papers, ISMF.

47. Receipt to Sarah Barry from John Leany, July 19, 1817, Barry-Hayes Papers, ISMP.

48. John Leamy to Sarah Barry, October 25, 1827, Barry-Hayes Papers, ISMP. 
suaded is become a very necessary Language for our Youths and will be more so by and by." 49 Several days later, Leamy wrote another letter expressing gratitude to Hamilton for his attention "to my Boys [sic] morals and will thank you to order him to attend the Roman Catholic Church when there shall be service and in defect thereof to attend the Episcopal Church." $\mathrm{He}$ also relayed some general information regarding Hamilton's account at the Bank of Pennsylvania. And while he pointed out that daughter Louisa would be delighted to pay a visit to her friend Miss [Mary] Hamilton, Leamy remarked that "... without papa, she could not go and I cannot leave my Office at present." 50

Leamy's correspondent, James Hamilton, was born in Ireland and had settled in Carlisle; by 1806, he was president judge of the Ninth Judicial District. Active in the Presbyterian Church, Hamilton also served on the Board of Trustees of Dickinson College. ${ }^{51}$ How he and Leamy first met and then developed their personal and business relationships is unclear, but throughout the 1810 s, Leamy wrote letters that blended familial tidings, commercial information, and occasional political commentary. For example, in July 1811 he wrote: "The Cause of Spain and Portugal goes on well-I hope the Peninsula will 'ere long be cleared of its invaders." This wish gave way to more pointed remarks a month later:

I am much gratified by your friendly and patriotic sentiments respecting the virtuous Cause of Spain - they are a brave good people, alltho [sic] unfortunately without a well established Government and deserve a better fate - God grant they may fully succeed in exterminating every hostile Frenchman from the Peninsula. ${ }^{52}$

By September 29, 1815, Leamy wrote, "I am in the City every day attending to my official duties," while on February 12, 1816, he lamented his "constant confinement to the Insurance business" in declining an invitation to bring his daughters to Carlisle for a visit. He did report, however vaguely, that his son was "agreeably situated and usefully employed." Towards the end of that year, Leamy reported that "our son ... was well at the last dates of his letters in October and has been so fortunate as to merit the full approbation of the highly respectable Gentlemen in whose House he is. " 53 By June 1819,

49. John Leamy to James Hamilton, Esq., Philadelphia, July 9, 1811, James Hamilton (1752-1819) Collection (hereafter JHC), No. 1612, HSP.

50. Leamy to Hamilton, Phila., July 18, 1811, JHC, HSP.

51. Biographical information on Hamilton is drawn from the HSP finding aid at http:/ / www.hsp.org/sites/www.hsp.org/files/migrated/findingaid l612hamilton.pdf.

52. Leamy to Hamilton, Phila., July 18 and August 20, 1811 , JHC, HSP.

53. Leamy to Hamilton, Phila., September 29, 1815, February 12, 1816, December 25 , $1816, \mathrm{JHC}, \mathrm{HSP}$. 
Copyright of U.S. Catholic Historian is the property of Catholic University of America Press and its content may not be copied or emailed to multiple sites or posted to a listserv without the copyright holder's express written permission. However, users may print, download, or email articles for individual use. 